Acta Crystallographica Section D

Biological Crystallography

ISSN 0907-4449

Salem Faham, ${ }^{a}$ Michael W. Day, William B. Connick, ${ }^{\mathbf{b}}$ Brian R. Crane, ${ }^{\mathrm{b}}$ Angel J. Di Bilio, ${ }^{\mathrm{b}}$ William P. Schaefer, ${ }^{\text {b }}$ Douglas C. Rees $^{\mathrm{a}, \mathrm{c}}$ and Harry B. Gray ${ }^{\mathrm{b}}$ *

a Division of Chemistry and Chemical Engineering, 147-75 CH, California Institute of Technology, Pasadena, California 91125, USA, beckman Institute, California Institute of Technology, Pasadena, California 91125, USA, and cHoward Hughes Medical Institute, California Institute of Technology, Pasadena, California 91125, USA

Correspondence e-mail: hgcm@its.caltech.edu

\title{
Structures of ruthenium-modified Pseudomonas aeruginosa azurin and $\left[\mathrm{Ru}\left(2,2^{\prime} \text {-bipyridine }\right)_{2}(\text { imidazole })_{2}\right] \mathrm{SO}_{4} \cdot 10 \mathrm{H}_{2} \mathrm{O}$
}

The crystal structure of $\mathrm{Ru}\left(2,2^{\prime} \text {-bipyridine }\right)_{2}$ (imidazole) (His83)azurin (RuAz) has been determined to $2.3 \AA$ resolution by X-ray crystallography. The spectroscopic and thermodynamic properties of both the native protein and $\left[\mathrm{Ru}\left(2,2^{\prime} \text {-bipyridine }\right)_{2}(\text { imidazole })_{2}\right]^{2+}$ are maintained in the modified protein. Dark-green $\mathrm{RuAz}$ crystals grown from PEG 4000, $\mathrm{LiNO}_{3}, \mathrm{CuCl}_{2}$ and Tris buffer are monoclinic, belong to the space group $C 2$ and have cell parameters $a=$ 100.6, $b=35.4, c=74.7 \AA$ and $\beta=106.5^{\circ}$. In addition, $\left[\mathrm{Ru}\left(2,2^{\prime}-\right.\right.$ bipyridine $)_{2}$ (imidazole $\left.)_{2}\right] \mathrm{SO}_{4} \cdot 10 \mathrm{H}_{2} \mathrm{O}$ was synthesized, crystallized and structurally characterized by X-ray crystallography. Red-brown crystals of this complex are monoclinic, space group $P 2_{1} / n$, unit-cell parameters $a=13.230$ (2), $b=18.197$ (4), $c=16.126$ (4) $\AA, \beta=108.65$ (2) ${ }^{\circ}$. Stereochemical parameters for the refinement of $\mathrm{Ru}\left(2,2^{\prime} \text {-bipyridine }\right)_{2}$ (imidazole)(His83) were taken from the atomic coordinates of $\left[\mathrm{Ru}\left(2,2^{\prime}\right.\right.$-bipyridine $\left.)_{2}(\text { imidazole })_{2}\right]^{2+}$. The structure of RuAz confirms that His 83 is the only site of chemical modification and that the native azurin structure is not perturbed significantly by the ruthenium label.

\section{Introduction}

Azurin $(\mathrm{Az})$ is a blue-copper protein that mediates electron flow in the denitrifying chains of certain bacteria (Adman, 1991). It has played an important role in the development of a model of electron tunnelling through protein structures (Regan et al., 1995, 1998; Gehlen et al., 1996; Stuchebrukhov, 1996; Gray \& Winkler, 1996; Daizadeh et al., 1997; Farver \& Pecht, 1997; Winkler \& Gray, 1997). The primary structure of Pseudomonas aeruginosa azurin consists of 128 amino acids. Its three-dimensional structure (Adman, 1991; Nar et al., $1991 a, b)$ features eight $\beta$-strands which form a $\beta$-barrel and one short $\alpha$-helix composed of residues 55-67. The copper site caps the top of the $\beta$-barrel, with two ligands supplied from $\beta$-strand 4 and three ligands from the loop connecting $\beta$-strands 7 and 8 . The copper ligands include the $\mathrm{N}^{\delta 1}$ atoms of His46 and His117 and the $\mathrm{S}^{\gamma}$ of Cys112, which form an approximately trigonal $\mathrm{CuN}_{2} \mathrm{~S}$ coordination unit. The copper coordination sphere is completed by weak axial interactions from the $\mathrm{S}^{\delta}$ of Met121 and the carbonyl $\mathrm{O}$ atom of Gly45 (bond lengths $\sim 3 \AA$ ). An unusually small inner-sphere $\mathrm{Cu}^{2+/+}$ reorganization energy is likely to facilitate electron transfer between donor and acceptor molecules (Gray \& Winkler, 1996; Solomon et al., 1996; Fraga et al., 1996; Di Bilio et al., 1997; Skov et al., 1998).

Spectroscopic and electrochemical measurements suggest that the active-site structures of metalloproteins are not significantly perturbed by ruthenium modification (Bjerrum et al., 1995). Since we would like to make direct structural
Received 29 January 1998 Accepted 27 July 1998

PDB Reference: rutheniummodified azurin, 1 bex.
(C) 1999 International Union of Crystallography Printed in Denmark - all rights reserved 
comparisons between native and Ru-modified proteins, we have crystallized and solved the structure of Pseudomonas aeruginosa azurin modified at $\mathrm{His} 83$ with $\mathrm{Ru}\left(2,2^{\prime}\right.$-bipyridine $)_{2}$ (imidazole $)^{2+}$ (Day, 1995). We have also determined the structure of $\left[\mathrm{Ru}\left(2,2^{\prime} \text {-bipyridine }\right)_{2}(\text { imidazole })_{2}\right] \mathrm{SO}_{4} \cdot 10 \mathrm{H}_{2} \mathrm{O}$; the stereochemical parameters for the ruthenium center in the modified protein $(\mathrm{RuAz})$ were taken from this structure.

\section{Experimental}

\subsection{Synthesis of $\left[\operatorname{Ru}\left(2,2^{\prime} \text {-bipyridine }\right)_{2}(\text { imidazole })_{2}\right]$ - $\mathrm{SO}_{4} \cdot 10 \mathrm{H}_{2} \mathrm{O}$}

This complex was obtained in high yield by reacting [Ru(2,2'-bipyridine) $\left.{ }_{2} \mathrm{CO}_{3}\right] \cdot 4 \mathrm{H}_{2} \mathrm{O}$ (Johnson et al., 1978; Kimura et al., 1982) or $\left[\mathrm{Ru}\left(2,2^{\prime} \text {-bipyridine }\right)_{2} \mathrm{Cl}_{2}\right] \cdot 2 \mathrm{H}_{2} \mathrm{O}$ (Strem) with $2 M$ imidazole in aqueous solution at $353 \mathrm{~K}$ for nearly $2 \mathrm{~h}$. Solid $\left(\mathrm{NH}_{4}\right)_{2} \mathrm{SO}_{4}$ was added to the reaction mixture until a red-brown microcrystalline precipitate formed. The solid was dissolved in water and loaded onto a cation-exchange gravity column packed with S- or SP-Sepharose (Pharmacia) and eluted with a stepwise gradient of $\left(\mathrm{NH}_{4}\right)_{2} \mathrm{SO}_{4}$. The column was protected from room light during the separation. Only the luminescent band was collected. The complex precipitated as a microcrystalline solid upon concentration (care was taken to keep the solution at $313 \mathrm{~K}$ or lower during concentration). Red-brown crystals suitable for X-ray structure determination were grown in the dark by slow evaporation of an aqueous solution containing $1 M\left(\mathrm{NH}_{4}\right)_{2} \mathrm{SO}_{4}$ at $277 \mathrm{~K}$. UV-VIS spectrum in aqueous phosphate buffer $\left[\lambda_{\max }(\mathrm{nm}), \varepsilon\left(M^{-1} \mathrm{~cm}^{-1}\right)\right.$ in parentheses]: 242.6 (22140), 291.8 (57471), 342.2 (7360), 436 (sh), 491.6 (8400). Emission spectrum (aqueous buffer): $\lambda_{\max }$ $\simeq 670 \mathrm{~nm} .400 \mathrm{MHz}{ }^{1} \mathrm{H}$ NMR $\left(\mathrm{CD}_{3} \mathrm{OD}\right): \delta 9.03(\mathrm{ddd}, 1 \mathrm{H}, J=$ $5.7,1.3,0.6 \mathrm{~Hz}), 8.50(\mathrm{~d}, 1 \mathrm{H}, J=8.1 \mathrm{~Hz}), 8.43(\mathrm{~d}, 1 \mathrm{H}, J=$ $8.1 \mathrm{~Hz}), 8.10(\mathrm{ddd}, 1 \mathrm{H}, J=8.0,7.7,1.4 \mathrm{~Hz}), 7.98(\mathrm{ddd}, 1 \mathrm{H}, J=$ 5.6, 1.4, $0.7 \mathrm{~Hz}), 7.89$ (ddd, $1 \mathrm{H}, J=8.1,7.7,1.4 \mathrm{~Hz}), 7.74(\mathrm{ddd}$, $1 \mathrm{H}, J=7.6,5.6,1.3 \mathrm{~Hz}), 7.70(\mathrm{dd}, 1 \mathrm{H}, J=1.3,1.3 \mathrm{~Hz}), 7.34$ $(\mathrm{ddd}, 1 \mathrm{H}, J=7.6,5.7,1.3 \mathrm{~Hz}), 7.12(\mathrm{dd}, 1 \mathrm{H}, J=1.5,1.5 \mathrm{~Hz})$, $6.75(\mathrm{dd}, 1 \mathrm{H}, J=1.4,1.4 \mathrm{~Hz})$. Analysis calculated for $\mathrm{C}_{26} \mathrm{H}_{44} \mathrm{~N}_{8} \mathrm{O}_{14} \mathrm{SRu}: \mathrm{C}, 37.8 \%$; H, 5.37\%; N, 13.6\%. Found: C, $36.5 \%$; H, $5.7 \%$; N, 14.4\%.

\subsection{Structure determination of $\left[R u\left(2,2^{\prime} \text {-bipyridine }\right)_{2}\right.$ - (imidazole) $\left.{ }_{2}\right] \mathrm{SO}_{4} \cdot 10 \mathrm{H}_{2} \mathrm{O}$}

Diffraction data were collected at room temperature on an Enraf-Nonius CAD4 diffractometer (Mo $K \alpha$ radiation and graphite monochromator). The unit cell (monoclinic) was determined from the setting angles of 25 reflections with $9 \leq \theta \leq 13^{\circ}$; the space group $\left(P 2_{1} / n\right)$ was determined from systematic absences. Intensities were corrected for Lorentz and polarization effects, as well as for decay based on three standard reflections measured every $150 \mathrm{~min}$ (total decay, $13.8 \%$ ). Altogether, 3433 independent reflections to a $2 \theta$ of $40^{\circ}$ (7815 measurements; $R_{\text {merge }}=0.031$ for 2537 duplicates, $\mathrm{GOF}_{\text {merge }}=0.97$ for 3292 multiples) were collected $(+h, \pm k, \pm l)$; three reflections with obvious errors were discarded, leaving a total of 3430 data. The $\mathrm{Ru}$ coordinates were obtained from Patterson maps, and remaining non- $\mathrm{H}-$ atom positions were determined from successive structurefactor and Fourier calculations. Ligand $\mathrm{H}$ atoms were positioned by calculation $(\mathrm{C}-\mathrm{H}, \mathrm{N}-\mathrm{H}, 0.95 \AA)$ and were assigned isotropic $B$ values approximately 1.15 times those of the bonded atoms. The large displacement parameters of the water $\mathrm{O}$ atoms, as well as two moderately large peaks in the

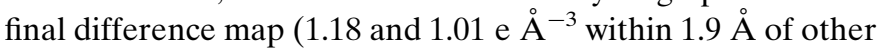
water molecules) and the observed decay during data collection, are consistent with partial water occupancy and disorder. Thus, the exact water content is uncertain; however, the current model agrees satisfactorily with the elemental analysis. The crystals are composed of discrete cations, anions and solvent linked together by hydrogen bonds. However, in view of the uncertainties in water content, we did not develop a model for the hydrogen bonding among the sulfate $\mathrm{O}$ atoms, $\mathrm{N} 7$ and N8 of the imidazole ligands and the water molecules. Least-squares refinement of this model converged to give an $R$ factor $\left(=\sum\left|F_{o}-F_{c}\right| / \sum\left|F_{o}\right|\right)$ of 0.074 for 2443 reflections with $F_{o}^{2}>3 \sigma\left(F_{o}^{2}\right), 0.091$ for 3070 reflections with $F_{o}^{2}>0$ and a $\mathrm{GOF}=\sum w\left[\left(F_{o}^{2}-F_{c}^{2}\right)^{2} /(n-p)\right]^{1 / 2}$ of 3.53 for 3429 data and 411 parameters (interchanging N7 and C22 of the ligands, as well as N8 and C25, gives higher values of $R$ and GOF indicating that their original assignments are correct). Weights were taken as $1 / \sigma^{2}\left(F_{o}^{2}\right)$, and variances $\sigma^{2}\left(F_{o}^{2}\right)$ were derived from counting statistics plus an additional term, $\left(0.014 F_{o}^{2}\right)^{2}$. Variances of the merged data were determined by propagation of error plus another additional term, $\left(0.014\left\langle F_{o}^{2}\right\rangle\right)^{2}$. Atomic scattering factors were taken from Cromer \& Waber (Cromer \& Waber, 1974; Cromer, 1974). Computer programs were those of the CRYM crystallographic computing system (Duchamp, 1964).

\subsection{Modification of azurin}

Recombinant azurin was prepared as described (Piccioli et $a l ., 1995)$ and purified, prior to reconstitution with $\mathrm{Cu}^{2+}$, by anion-exchange chromatography [Mono-Q column; DEA (diethanolamine) buffer, $\mathrm{pH}$ 9.0] on a Pharmacia FPLC (fast protein liquid chromatography) system. This chromatographic step allowed for the separation of $\mathrm{AzZn}^{2+}$ from the apo protein. After reconstitution with copper, the protein was repurified by cation-exchange chromatography (Mono-S column; NaOAc buffer $\mathrm{pH} 4.5)$. Oxidized azurin $\left(A_{628} / A_{280} \simeq\right.$ $0.60-0.62)$ was equilibrated with aqueous $\mathrm{NaHCO}_{3}(300 \mathrm{~m} M$, $\mathrm{pH} 8.3$ ) and the concentration of protein adjusted to 0.1$0.2 \mathrm{~m} M$. An equivalent of $\mathrm{Ru}\left(2,2^{\prime} \text {-bipyridine }\right)_{2}^{2+}$ \{as freshly dissolved $\left[\mathrm{Ru}\left(2,2^{\prime} \text {-bipyridine }\right)_{2} \mathrm{CO}_{3}\right] \cdot 4 \mathrm{H}_{2} \mathrm{O}$ in $300 \mathrm{mM}$ $\left.\mathrm{NaHCO}_{3}\left(\lambda_{\max }=510 \mathrm{~nm}, \varepsilon \simeq 9200 \mathrm{M}^{-1} \mathrm{~cm}^{-1}\right)\right\}$ was added to the azurin solution. The mixture was allowed to react for several hours in a capped vial at room temperature. $\mathrm{Ru}\left(2,2^{\prime} \text {-bipyridine }\right)_{2}\left(\mathrm{H}_{2} \mathrm{O}\right)(\mathrm{His} 83) \mathrm{Az} \quad\left[\lambda_{\max } \quad(\mathrm{Ru}) 488 \mathrm{~nm}\right.$; $>90 \%$ yield] was isolated by means of cation-exchange chromatography. Small variations of the reaction conditions did not affect the yield of azurin modified at His83. Note, however, that a substantial proportion of azurin modified at other amino acids formed when the coupling reaction was conducted in sodium phosphate buffer. The binding of the 
$\mathrm{Ru}\left(2,2^{\prime} \text {-bipyridine }\right)_{2}\left(\mathrm{H}_{2} \mathrm{O}\right)^{2+}$ group to His83 is irreversible. Exchange of the water molecule coordinated to the $\mathrm{Ru}$ atom of $\mathrm{Ru}\left(2,2^{\prime} \text {-bipyridine }\right)_{2}\left(\mathrm{H}_{2} \mathrm{O}\right)(\mathrm{His} 83) \mathrm{Az}$ by imidazole was achieved by equilibrating the ruthenated azurin with a solution containing $500 \mathrm{~m} M$ imidazole, $100 \mathrm{mM} \mathrm{NaCl}$ and $1 \mathrm{~m} M$ $\mathrm{CuSO}_{4}$ ( $\mathrm{pH}$ 7.5). The exchange reaction was allowed to take place for at least $4 \mathrm{~d}$ at room temperature, to give $\mathrm{RuAz}\left[\lambda_{\max }\right.$ $(\mathrm{Ru}): 491 \mathrm{~nm}, 436 \mathrm{~nm}(\mathrm{sh})] . \mathrm{RuAzCu}^{2+}$ is a green protein, whereas $\mathrm{RuAzCu}^{+}$(obtained by addition of ascorbate or dithionite) is orange. Unlike $\mathrm{Ru}\left(2,2^{\prime} \text {-bipyridine }\right)_{2}$ $\left(\mathrm{H}_{2} \mathrm{O}\right)(\mathrm{His} 83) \mathrm{Az}$, both $\mathrm{RuAzCu}{ }^{2+}$ and $\mathrm{RuAzCu}^{+}$are weakly luminescent (emission $\lambda_{\max } \simeq 670 \mathrm{~nm}$ ). RuAz was stored at $277 \mathrm{~K}$ in the same imidazole-containing buffer and was repurified before use.

2.3.1. $\mathrm{p} /$ determination of RuAz. Isoelectric focusing was performed in three $1.44 \times 160 \mathrm{~mm}$ tube gels, composed of $5 \%$ polyacrylamide with $2.5 \%$ crosslinking (piperazine diacrylate), containing $2.5 \%$ carrier ampholyte solution $(\mathrm{pH}$ range $3-10)$. No urea or detergents were used. RuAz solution $(20 \mu \mathrm{l})$ was applied at the cathodic end of the gel (catholyte and

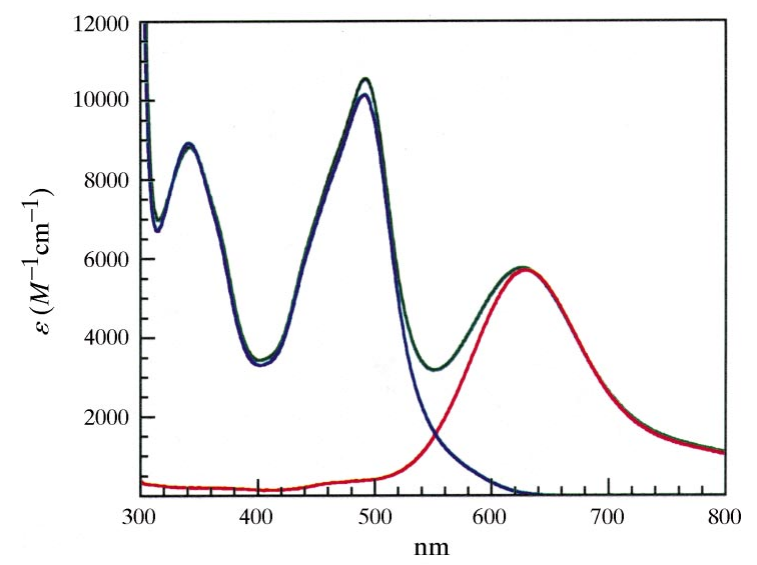

(a)

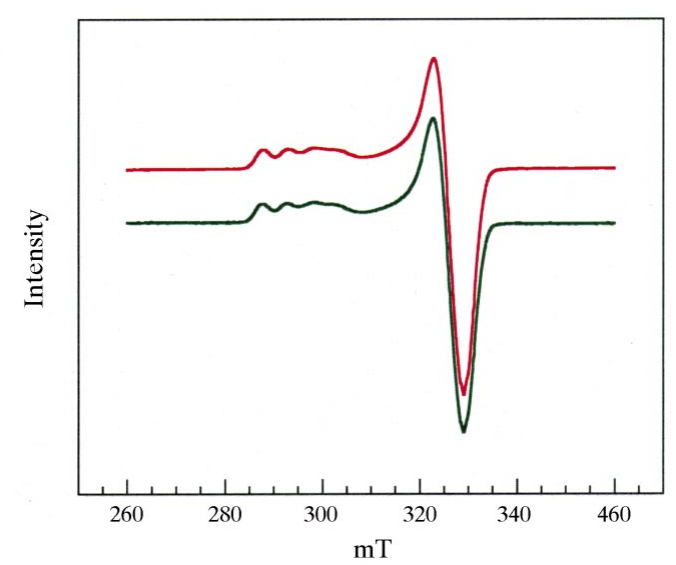

(b)

Figure 1

(a) Absorption spectra of native azurin (red), $\left[\mathrm{Ru}\left(2,2^{\prime} \text {-bipyridine }\right)_{2}\right.$ (imidazole) $\left.{ }_{2}\right]^{2+}$ (blue), and $\mathrm{RuAz}$ (green) in aqueous buffer at room temperature. $(b)$ Comparison of the EPR spectra of native azurin (red) and $\mathrm{RuAz}$ (green). The EPR spectra were recorded at $77 \mathrm{~K}$ in a 1:1 mixture of glycerol and $25 \mathrm{~m} M$ HEPES [4-(2-hydroxyethyl)-1-piperazine ethanesulfonic acid] buffer at $\mathrm{pH}$ 7.5. anolyte solutions were $10 \mathrm{~m} M \mathrm{NaOH}$ and $6 \mathrm{~m} M \mathrm{H}_{3} \mathrm{PO}_{4}$, respectively) and constant voltage was applied at $200 \mathrm{~V}$ for $4 \mathrm{~h}, 500 \mathrm{~V}$ for $2 \mathrm{~h}$ and $800 \mathrm{~V}$ for $12 \mathrm{~h}$. The gel was hydrostatically extruded from the tube and the colored band of azurin was excized with a razor blade and placed in $1 \mathrm{ml}$ of $0.1 M \mathrm{KCl}$ for $1 \mathrm{~h}$. The $\mathrm{pH}$ of this solution was measured with a calibrated Beckman $\mathrm{pH}$ electrode (S404A) and found to be 6.35 at $298 \mathrm{~K}$ in the three different experiments. The $\mathrm{p} I$ for native azurin is 5.40 (Fee, 1975).

\subsection{Crystal growth}

Crystals were obtained by equilibrating a $7 \mu \mathrm{l}$ drop containing $3.5 \mu \mathrm{l}$ of well solution and $3.5 \mu \mathrm{l} \mathrm{RuAz}$ solution (approximately $30 \mathrm{mg} \mathrm{ml}^{-1}$ in $100 \mathrm{mM} \mathrm{NaOAc} \mathrm{pH} \mathrm{5.0)} \mathrm{against}$ a well solution of $30 \%(w / v)$ PEG $4 \mathrm{~K}, 100 \mathrm{~m} M \mathrm{LiNO}_{3}$ and $20 \mathrm{mM} \mathrm{CuCl}{ }_{2}$ buffered at $\mathrm{pH} 8.0$ with $100 \mathrm{~m} M$ Tris [tris(hydroxymethyl)aminomethane]. After one week, dark green monoclinic crystals of space group $C 2$ grew to a final size of $0.1 \times 0.3 \times 0.3 \mathrm{~mm}$.

\subsection{Data collection}

$2.3 \AA$ resolution X-ray diffraction data were collected from RuAz crystals with a Siemens X-1000 multi-wire area detector using $\mathrm{X}$-rays generated by a Siemens rotating copper anode $[\mathrm{Cu} K \alpha$ radiation $(\lambda=1.5418 \AA)]$ and graphite monochromator. The data were collected at approximately $100 \mathrm{~K}$ using cryogenic techniques (Hope, 1988, 1990). About $1 \mathrm{ml}$ of $50 \%$ glycerol solution was added as cryoprotectant to the drop the crystal was grown in. Subsequently, the data were processed and scaled using the program XENGEN (Howard et al., 1987). Altogether, 38571 observations were collected containing 11083 unique reflections (13540 possible, 82\%

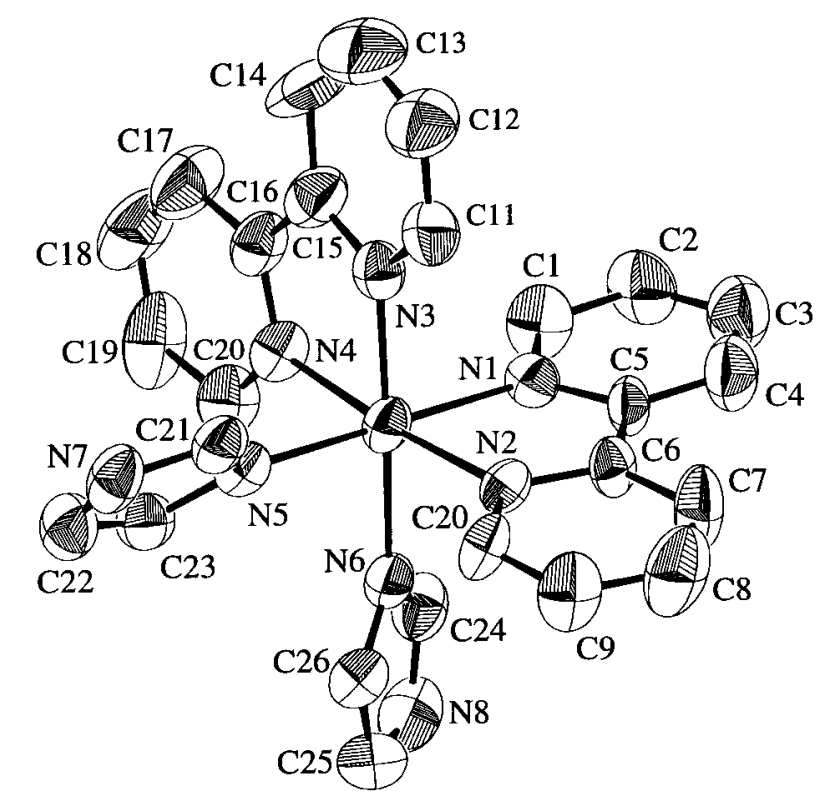

Figure 2

ORTEPII drawing of $\left[\mathrm{Ru}\left(2,2^{\prime} \text {-bipyridine }\right)_{2}(\text { imidazole })_{2}\right]^{2+}$ showing the atom-numbering system. Atoms are shown as $50 \%$ probability ellipsoids. $\mathrm{H}$ atoms are not shown. The dication is in the $\Delta$ configuration. 
complete). The data set had an overall $R_{\text {merge }}$ of $6.3 \%(17.0 \%$ for data between 2.3 and $2.4 \AA$ resolution) with an average $I / \sigma(I)=16.7$ (4.2, for data between 2.3 and $2.4 \AA$ resolution) and an overall $B$ value, calculated from Wilson statistics, of $34.3 \AA^{2}$.

\subsection{Structure solution and refinement}

The structure of RuAz was determined by molecular replacement using an early structure of the Cys112Asp mutant of Pseudomonas aeruginosa azurin with copper ion removed as a search model (Faham et al., 1997). The orientation of the model was determined with the fast-rotation function of Crowther and Blow (Crowther, 1972) using all data between 8 and $3.5 \AA$ resolution with an integration radius of $17 \AA$. The self-rotation function contained peaks at nearly half the value of the peaks given by the crystallographic twofold axis. The non-crystallographic self-rotation peaks had spherical polar angles $(\varphi, \psi, \kappa)=\left(200,85,180^{\circ}\right)$ and $\left(290,90,189^{\circ}\right)$, where $\psi$ is measured from the $b$ axis and $\varphi$ is the angle projected onto the $a c$ plane, with $\varphi=0$ corresponding to the $a$ axis. This result indicated that there were two molecules related by non-crystallographic symmetry in the asymmetric unit, consistent with our estimation of eight molecules in the unit cell based on the ratio of cell volume to molecular weight $\left(V_{m}=2.18 \AA^{3} \mathrm{Da}^{-1}\right.$; Matthews, 1968). The cross-rotation function contained peaks related to each other by the same angles as peaks in the selfrotation function.

The position in the unit cell of one properly oriented molecule was determined by a brute-force translation search in the $x z$ plane using data between 8 and $5 \AA$, which yielded a correlation coefficient of 0.28 , compared with 0.25 for the next highest peak. The position of the second molecule was determined by fixing the position of the first molecule and performing a translation search between $x=0$ and $1, y=0$ and $1 / 2$, and $z=0$ and 1 . The resulting solution gave a correlation coefficient of 0.43 , compared with 0.30 for the next highest peak. For reference, the two molecules in the asymmetric unit are designated $A$ and $B$. The crystallographic $R$ factor for the rotated and translated model (calculated with the refinement
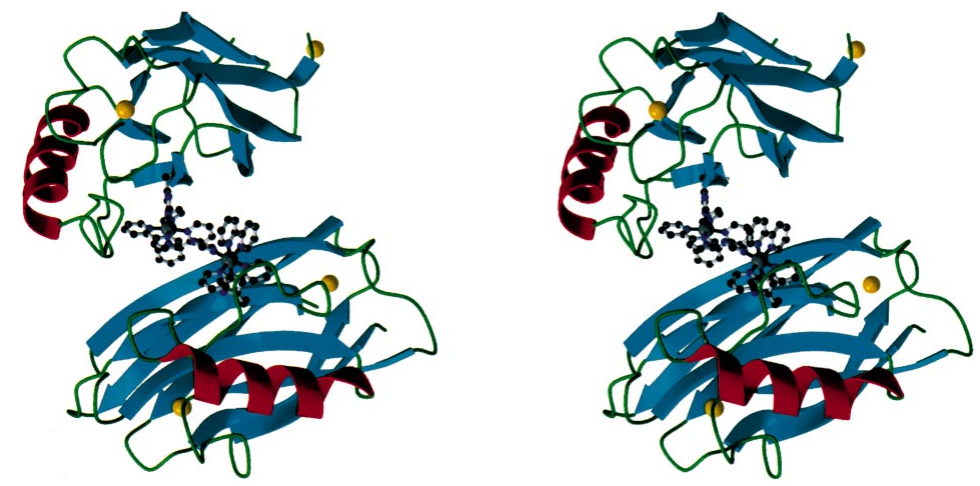

Figure 3

Ribbon stereodiagram showing the polypeptide fold and packing interaction between the two RuAz molecules in the asymmetric unit. The $\operatorname{Ru}\left(2,2^{\prime}\right.$ bipyridine $)_{2}$ group is found at the interface. package TNT; Tronrud et al., 1987) was $R=47.9 \%$ for data between 8 and $3.0 \AA$ resolution.

Difference Fourier electron-density maps $\left(F_{o}-F_{c}\right)$ revealed one $7 \sigma$ peak near each His83, one $5 \sigma$ peak at each blue-copper site and one $5 \sigma$ peak beside each $\mathrm{N}$-terminus. The $7 \sigma$ peaks reside in the plane of each His 83 and were therefore modeled as the $\mathrm{Ru}$ atoms of the label; the $5 \sigma$ blue-copper site peaks were modeled as copper and the $5 \sigma$ peaks near the $\mathrm{N}$-terminus were also modeled as copper in consideration of the dependence of crystal growth on $\mathrm{CuCl}_{2}$ and our findings from the previous Cys112Asp azurin structure (Faham et al., 1997).

Because the ruthenium complex used to prepare $\mathrm{RuAz}$ is racemic, both $\Delta-\mathrm{RuAz}$ and $\Lambda-\mathrm{RuAz}$ optical isomers are present in solution in similar proportions [a 1:1 mixture of azurin and $\mathrm{Ru}\left(2,2^{\prime}\right.$-bipyridine $) \mathrm{CO}_{3}$ reacts to give $\mathrm{Ru}\left(2,2^{\prime}\right.$ bipyridine $)\left(\mathrm{H}_{2} \mathrm{O}\right)(\mathrm{His} 83) \mathrm{Az}$ in $>90 \%$ yield]. These isomers are structurally quite similar and could not be resolved by means of standard chromatographic methods. The racemic mixture was used for crystal growth. Despite the expected complications due to the presence of both isomers, after several rounds of refinement the difference Fourier maps showed electron density for the $2,2^{\prime}$-bipyridine ligands; the ligands for the Ru atom in molecule $A$ are likely to be in the $\Delta$ configuration, while the ligands for the Ru atom in molecule $B$ are less defined in the electron density, and have been built in the $\Lambda$ configuration. For all subsequent cycles of refinement, stereochemical restraints were applied to the $\mathrm{Ru}\left(2,2^{\prime}\right.$-bipyridine $)_{2}$ (imidazole) group. The final model includes 92 solvent $\mathrm{O}$ atoms and resulted in a crystallographic residual ( $R$ factor) of $20.9 \%$ between 20.0 and $2.3 \AA$ resolution $(26.7 \%$ for data between 2.4 and $2.3 \AA$ resolution) and a free $R$ of $28.9 \%$ (36.5\% for data between 2.4 and $2.3 \AA$ resolution). Noncrystallographic symmetry positional restraints were used in the refinement on all protein atoms. Final refinement as well as the bulk solvent correction was performed with $X-P L O R$ (Brünger et al., 1987). The r.m.s. deviations of the bond distances and angles from the target values are $0.013 \AA$ and $1.75^{\circ}$, respectively. $86 \%$ of protein residues fall into the most favorable region of the Ramachandran plot as defined by PROCHECK (Laskowski et al., 1993), with no residues in the disallowed regions. The average temperature factors for main-chain and side-chain atoms are $B=10.7$ and $11.8 \AA^{2}$, respectively. The average temperature factors for molecules $A$ and $B$ are $B=11.6$ and $12.0 \AA^{2}$, respectively. The average temperature factor for solvent $\mathrm{O}$ atoms is $B=18.6 \AA^{2}$.

Figs. 3, 4, 5 and 6 were prepared with the programs MOLSCRIPT (Kraulis, 1991) and Raster3D (Bacon \& Anderson, 1988; Merritt \& Murphy, 1994).

\section{Results and discussion}

\subsection{Spectra and reduction potentials}

The absorption spectrum of RuAz is the sum of the absorption spectra of native azurin and $\left[\mathrm{Ru}\left(2,2^{\prime}\right.\right.$-bipyr- 
idine $\left.)_{2}(\text { imidazole })_{2}\right]^{2+}$ (Fig. 1a). The X-band frozen-solution EPR spectra of native azurin and RuAz (Fig. 1b) are identical. The EPR spectra were recorded on protein samples reconstituted with ${ }^{63} \mathrm{Cu}$. The measured spin-Hamiltonian parameters, $g_{\|}=2.26, A_{\|} \simeq 65 \times 10^{-4} \mathrm{~cm}^{-1}$ and $g_{\perp}=2.05$, are in agreement with literature values (Fee, 1975; Antholine et al., 1993). Values for the reduction potentials of both redox centers in $\mathrm{RuAz}\left[E\left(\mathrm{Cu}^{2+/+}\right)=0.326 \mathrm{~V}\right.$ and $E\left(\mathrm{Ru}^{3+/ 2+}\right)=$ $1.082 \mathrm{~V}$ versus NHE] are close to those for native azurin $\left[E\left(\mathrm{Cu}^{2+/+}\right)=0.325 \mathrm{~V}\right]$ and $\left[\mathrm{Ru}\left(2,2^{\prime} \text {-bipyridine }\right)_{2}{ }^{-}\right.$ (imidazole $\left.)_{2}\right]^{2+}\left[E\left(\mathrm{Ru}^{3+/ 2+}\right)=1.006 \mathrm{~V}\right]$ (Di Bilio et al., 1997). These data clearly show that the copper and the ruthenium sites of RuAz are weakly coupled. The reduction potential of the copper site is not affected by the presence of the ruthenium cation. However, the reduction potential of the attached ruthenium complex is slightly more positive than that of the free complex. This increase in potential is likely to arise from the expected decrease in the exposure of the ruthenium center to the aqueous environment when coordinated to azurin.

\subsection{Crystal structure of $\left[\operatorname{Ru}\left(2,2^{\prime} \text {-bipyridine }\right)_{2^{-}}\right.$ (imidazole $\left.)_{2}\right] \cdot 10 \mathrm{H}_{2} \mathrm{O}$}

The crystal structure of $\left[\mathrm{Ru}\left(2,2^{\prime} \text {-bipyridine }\right)_{2}\right.$ (imidazole $\left.)_{2}\right] \mathrm{SO}_{4} \cdot 10 \mathrm{H}_{2} \mathrm{O}$ was determined in order to obtain bond distances and angles for the refinement of the $\mathrm{Ru}\left(2,2^{\prime}\right.$ bipyridine $)_{2}$ (imidazole)(His83) part of RuAz. The coordination geometry around the $\mathrm{Ru}$ center is approximately octa-

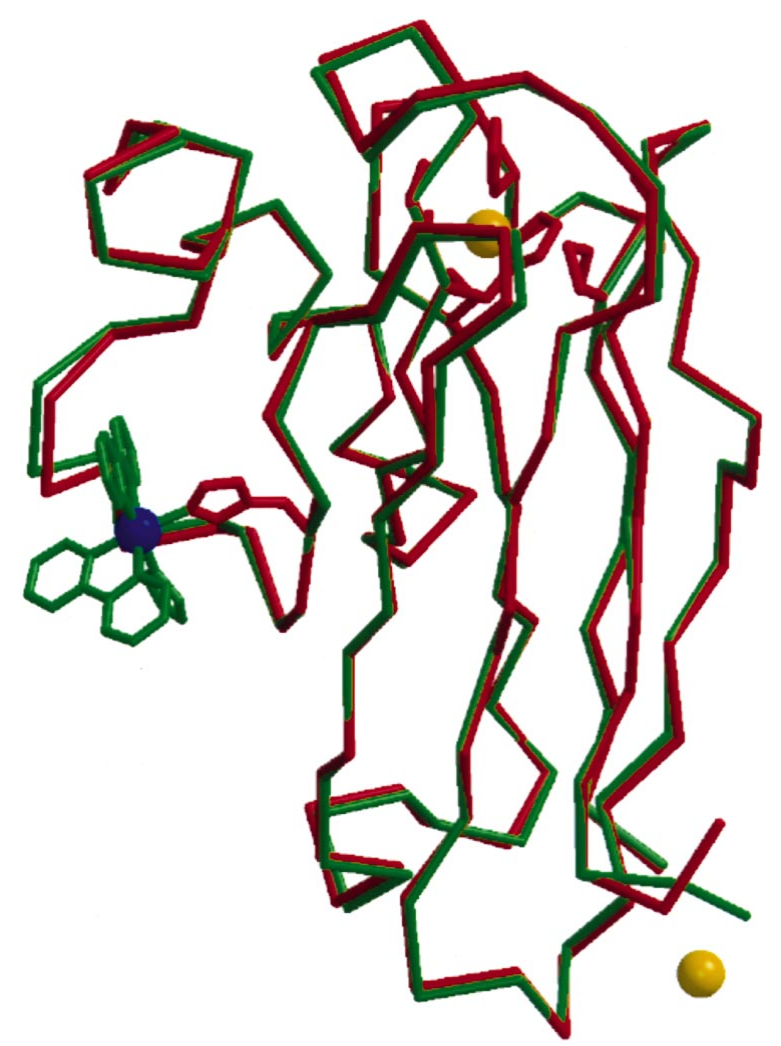

Figure 4

Superposition of the RuAz (green) structure with the native azurin (red) structure (PDB code 4AZU) based on residues 3-128.
Table 1

Selected geometric parameters for $\left[\mathrm{Ru}\left(2,2^{\prime} \text {-bipyridine }\right)_{2}(\text { imidazole })_{2}\right]^{2+}$.

\begin{tabular}{lr}
\hline Bond lengths $(\AA)$ & \\
\hline $\mathrm{Ru}-\mathrm{N} 1$ & $2.043(10)$ \\
$\mathrm{Ru}-\mathrm{N} 2$ & $2.059(10)$ \\
$\mathrm{Ru}-\mathrm{N} 3$ & $2.042(11)$ \\
$\mathrm{Ru}-\mathrm{N} 4$ & $2.062(11)$ \\
$\mathrm{Ru}-\mathrm{N} 5$ & $2.096(11)$ \\
$\mathrm{Ru}-\mathrm{N} 6$ & $2.093(11)$ \\
\hline & \\
\hline Bond angles $\left(^{\circ}\right)$ & \\
\hline $\mathrm{N} 1-\mathrm{Ru}-\mathrm{N} 2$ & \\
$\mathrm{~N} 1-\mathrm{Ru}-\mathrm{N} 3$ & $78.4(4)$ \\
$\mathrm{N} 1-\mathrm{Ru}-\mathrm{N} 4$ & $88.6(4)$ \\
$\mathrm{N} 1-\mathrm{Ru}-\mathrm{N} 5$ & $96.7(4)$ \\
$\mathrm{N} 1-\mathrm{Ru}-\mathrm{N} 6$ & $175.9(4)$ \\
$\mathrm{N} 2-\mathrm{Ru}-\mathrm{N} 3$ & $91.8(4)$ \\
$\mathrm{N} 2-\mathrm{Ru}-\mathrm{N} 4$ & $97.7(4)$ \\
$\mathrm{N} 2-\mathrm{Ru}-\mathrm{N} 5$ & $174.2(4)$ \\
$\mathrm{N} 2-\mathrm{Ru}-\mathrm{N} 6$ & $98.3(4)$ \\
$\mathrm{N} 3-\mathrm{Ru}-\mathrm{N} 4$ & $85.8(4)$ \\
$\mathrm{N} 3-\mathrm{Ru}-\mathrm{N} 5$ & $78.8(4)$ \\
$\mathrm{N} 3-\mathrm{Ru}-\mathrm{N} 6$ & $89.6(4)$ \\
$\mathrm{N} 4-\mathrm{Ru}-\mathrm{N} 5$ & $176.5(4)$ \\
$\mathrm{N} 4-\mathrm{Ru}-\mathrm{N} 6$ & $86.4(4)$ \\
$\mathrm{N} 5-\mathrm{Ru}-\mathrm{N} 6$ & $97.7(4)$ \\
& $90.3(4)$ \\
\hline
\end{tabular}

hedral with a cis arrangement of imidazole ligands (Fig. 2). The $\mathrm{Ru}-\mathrm{N}\left(2,2^{\prime}\right.$-bipyridine) [average: 2.05 (1) $\mathrm{A}$ ] distances are in excellent agreement with those observed for $\left[\mathrm{Ru}\left(2,2^{\prime}\right.\right.$ -

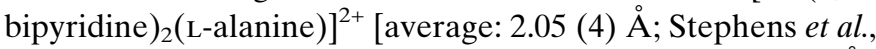
1983]. The Ru-N(imidazole) [2.096(11), 2.093 (11) ^] distances also are similar to that observed for trans, trans, trans- $\mathrm{RuCl}_{2}(\mathrm{DMSO})_{2}$ (imidazole $)_{2}$ [2.105 (4) А; Anderson \& Beauchamp, 1995]. Distances and angles of the ligands are as expected (Table 1).

\subsection{Crystal structure of RuAz}

The crystal structure of $\mathrm{RuAz}$ reveals that the ruthenium label does not significantly perturb the structure of azurin. In particular, the geometry of its copper center is identical with that of the unmodified protein. RuAz crystallizes with two crystallographically independent molecules (molecules $A$ and $B)$ in the asymmetric unit related by an approximate twofold axis of symmetry (Fig. 3). The protein components of the two molecules are virtually identical in structure, enabling the use of non-crystallographic symmetry restraints throughout refinement (r.m.s. deviation of $\mathrm{C} \alpha$ atoms $=0.03 \AA$ ). The $\mathrm{RuAz}$ structure is also very similar to that of native azurin (Nar et al., 1991a; PDB code 4AZU), with only a $0.37 \AA$ r.m.s. deviation in $\mathrm{C} \alpha$ positions for residues 3-128 (Fig. 4) and the expected copper-site bond distances: $\mathrm{Cu}-\mathrm{S}^{\gamma}(\mathrm{Cys} 112)=2.26 \AA, \mathrm{Cu}-$ $\mathrm{N}^{\delta 1}\left(\right.$ His46) $=2.08 \AA, \mathrm{Cu}-\mathrm{N}^{\delta 1}(\mathrm{His} 117)=2.08 \AA, \mathrm{Cu}-\mathrm{S}^{\delta}$ $($ Met121 $)=3.11 \AA$ and $\mathrm{Cu}-\mathrm{O}(\mathrm{Gly} 45)=2.99 \AA$. Bonddistance restraints for the copper site were taken from the structure of the azurin mutant His35Gln (Nar et al., 1991a).

The $\mathrm{Ru}\left(2,2^{\prime} \text {-bipyridine }\right)_{2}$ (imidazole $)^{2+}$ unit is covalently attached to His $83 \mathrm{~N}^{\varepsilon 2}$ and packs against an otherwise surfaceexposed loop between the lone $\alpha$-helix and the fifth $\beta$-strand of the azurin $\beta$ barrel. The ruthenium label buries $150 \AA^{2}$ of 
solvent-accessible surface area on the azurin molecule to which it is attached. The imidazole ring of His 83 forms a hydrogen bond with the carbonyl $\mathrm{O}$ atom of Thr84 [His83 $\mathrm{N}^{\delta 1} \ldots$ Thr84 O] and occupies the same position as found in native azurin. This hydrogen bond is found in all other crystal structures of $P$. aeruginosa azurins and is considered critical in understanding the $\mathrm{Cu}-\mathrm{Ru}$ electronic coupling in the modified protein (Regan et al. 1998). In addition to the covalent attachment to His83, interactions of the label with the protein are dominated by the packing of one $2,2^{\prime}$-bipyridine ligand against Leu73 in the center of the $\beta-\alpha$ loop and the close proximity of four negatively charged residues to the label: Asp71, Asp76, Asp77 and Asp93. This concentration of negatively charged residues is likely to facilitate the specific derivatization of His 83 by the positive ruthenium complex. Zinc(II) has also been shown to bind His83 of Pseudomonas putida azurin, further demonstrating the avidity of this position for cations (Chen et al., 1998). In RuAz, the residues Leu73, Lys74, Pro75, Asp76, Asp77, Val80, Ile81, Ala82 and His83 all contact the ruthenium label directly, whereas Thr30, Val31, Asn32, Lys41, Lys70, Asp71, Lys92, Asp93, Ser94, Val95 and Thr96 are within $7 \AA$ A. A slight conformational change is found in the region surrounding Asp76, the $\mathrm{C} \alpha$ of which moves $\sim 1.3 \AA$ in order to accommodate a 2,2'-bipyridine ligand.

The $\mathrm{Ru}$ atom and His83 ring are clearly defined for both RuAz molecules in $2.3 \AA$ resolution $F_{o}-F_{c}$ omit electrondensity maps (Fig. 5). The 2,2'-bipyridine ligand that contacts Leu73 is defined in molecule $A$ (Fig. $5 a$ ); however, the second 2,2'-bipyridine ligand and the imidazole are less discernible, especially in molecule $B$ (Fig. $5 b$ ). The Ru label must be fully occupied in the crystal lattice, because the reaction between azurin and $\mathrm{Ru}\left(2,2^{\prime} \text {-bipyridine }\right)_{2} \mathrm{CO}_{3}$ is irreversible and full
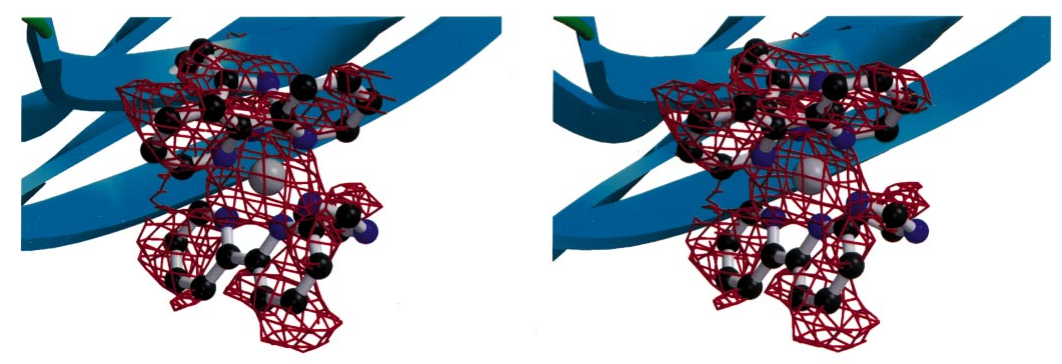

(a)

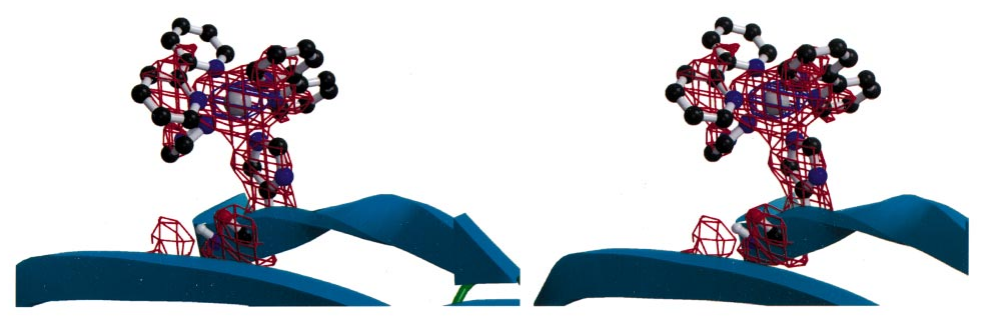

(b)

\section{Figure 5}

Stereodiagram showing the difference Fourier $\left(F_{o}-F_{c}\right)$ electron-density map, calculated without the ruthenium-label contributions to the model, contoured at $1.5 \sigma$ showing the electron density for the $\mathrm{Ru}\left(2,2^{\prime} \text {-bipyridine }\right)_{2}$ (imidazole)(His83) group on (a) molecule $A$ and (b) molecule $B$. derivatization of His83 was confirmed by optical spectroscopy (Fig. 1). However, the ancillary imidazole ligand may have been partially substituted by water, possibly explaining the reduced electron density cis to His83. \{Aqueous solutions of $\left[\mathrm{Ru}\left(2,2^{\prime} \text {-bipyridine }\right)_{2}(\text { imidazole })_{2}\right]^{2+}$ exposed to room light react slowly to give $\left[\mathrm{Ru}\left(2,2^{\prime} \text {-bipyridine }\right)_{2}\right.$ (imidazole)$\left.\left(\mathrm{H}_{2} \mathrm{O}\right)\right]^{2+}$. A Additionally (see $\left.\$ 2.6\right)$, two enantiomeric forms of $\mathrm{Ru}\left(2,2^{\prime} \text {-bipyridine }\right)_{2}$ (imidazole) may be present at each His83 site due to the racemic nature of the $\mathrm{Ru}(\mathrm{bpy})_{2} \mathrm{CO}_{3}$ used to derivatize the protein. As stated in $\S 2.6$, a $\Delta$ configuration for the ruthenium complex in molecule $A$ is most consistent with the observed electron density (Fig. 5a). However, some contribution from the $\Lambda$ isomer cannot be ruled out. Weak label ligand density makes determination of the isomer configuration in molecule $B$ (Fig. 5, bottom) difficult and indicates some conformational disorder of the ligand complex in the crystal lattice. Such disorder could be manifested by rotation of the $\mathrm{Ru}\left(2,2^{\prime} \text {-bipyridine }\right)_{2}$ (imidazole) group about the $\mathrm{Ru}-\mathrm{N}^{\varepsilon 2}$ (His83) bond, as well as partial or complete substitution of the ancillary imidazole ligand by water. The ruthenium atoms and the ligands refined to average temperature factors of $B=28.9$ and $22.7 \AA^{2}$, respectively.

The dimer interface formed in the crystal between molecule $A$ and molecule $B$ is relatively small and primarily mediated by the ruthenium complex. Molecule $A$ and molecule $B$ dimerize across an approximately twofold symmetric axis that associates residues $91-96$ of $\beta$-strand 6 of molecule $A$ with components of molecule $B$ that include the ruthenium complex, residues $27-32$ of $\beta$-strand 3 and residues 91-96 of $\beta$ strand 6. On each $\mathrm{RuAz}$ subunit, the dimeric association buries $250 \AA^{2}$ of surface area, which constitutes only $4.0 \%$ of the total solvent-exposed surface area of each subunit. Since soluble dimers typically bury at least $15 \%$ of their surface area (Janin et al., 1988), it is unlikely that this $\mathrm{RuAz}$ dimeric association would persist in solution. The approximately symmetric interface is dominated by the ruthenium complexes, which contribute 96.0 and $63.6 \AA^{2}$ of the interface surface area on molecules $A$ and $B$, respectively. Although the 2,2'bipyridine ligands are quite hydrophobic, all of the protein residues involved in the dimer interface are either charged or polar. In addition to the four negative residues near the label on the subunit to which it is attached, an additional negative residue, Asp59, reaches across from the other subunit to contact the positive ruthenium complex. Although the ruthenium complexes form a substantial portion of the dimer interface, they do not contact one another (they are separated by $\sim 8.0 \AA$ ).

Two exogenous copper sites were found in the structure of RuAz, each bound at the N-terminus of two crystallographically related protein molecules (Faham et al., 1997). Three ligands on the exogenous copper are supplied by one $\mathrm{RuAz}$ molecule: the $\mathrm{N}$-terminal amino $\mathrm{N}$ atom of Ala1, the carbonyl $\mathrm{O}$ atom of Ala1 and a carboxylate $\mathrm{O}$ atom of Asp23; a fourth ligand is supplied by the 

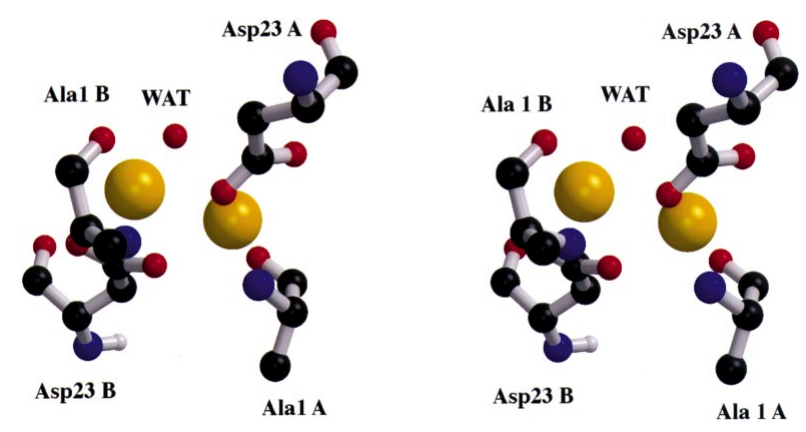

Figure 6

Stereodiagram showing the exogenous binuclear copper (yellow spheres) center coordinated by the amino and the carbonyl groups of Ala1, $\mathrm{O}^{\delta 1}$ and $\mathrm{O}^{\delta 2}$ of Asp23 from both molecules $A$ and $B$, and $\mathrm{O}$ from a bridging water molecule.

carboxylate $\mathrm{O}$ atom of symmetry-related Asp23 (Fig. 6). Thus, in this geometry one carboxylate of Asp23 bridges both coppers. A bridging water molecule completes the copper coordination sphere. Crystallographic twofold symmetry places both surface $\mathrm{Cu}$ atoms in close proximity, with a $\mathrm{Cu}-\mathrm{Cu}$ separation of nearly $3.0 \AA$. The different conformation of the Ala1-Glu2 peptide in RuAz relative to native azurin is attributable to the binding of copper in this region.

The distinct azurin dimer formed in this structure may result from the orientational requirements imposed by the surfacebound ruthenium complex and copper ion.

\section{Conclusions}

This is the first structure of a metalloprotein modified with a photoactive ruthenium-polypyridine complex. We have confirmed that the structure and the native properties of azurin are preserved in the modified protein. These results are crucial for the interpretation of electron tunneling in RuAz. It is logical to extend these findings to other ruthenium-metalloprotein complexes as well; thus, as long as the spectroscopic and thermodynamic properties of a protein are maintained in a surface-modified derivative, it is reasonable to assume that significant structural perturbations have not been introduced in the metal-site region.

We thank Michael Harrington, Jack Mizoguchi, Larry Henling and Jack Richards for helpful discussions. This work was supported by NIH (DK19038 to HBG; GM45162 to DCR)

\section{References}

Adman, E. T. (1991). Adv. Protein Chem. 42, 145-197.

Anderson, C. \& Beauchamp, A. L. (1995). Can. J. Chem. 73, 471-482. Antholine, W. E., Hanna, P. M. \& McMillin, D. R. (1993). Biophys. J. 64, 267-272.

Bacon, D. \& Anderson, W. F. (1988). J. Mol. Graph. 6, 219-220.

Bjerrum, M. J., Casimiro, D. R., Chang, I.-J., Di Bilio, A. J., Gray, H. B., Hill, M. G., Langen, R., Mines, G. A., Skov, L. K., Winkler, J. R. \& Wuttke, D. S. (1995). J. Bioenerg. Biomembr. 27, 295-277.
Brünger, A. T., Kuriyan, J. \& Karplus, M. (1987). Science, 235, 458460.

Chen, Z.-W., Barber, M. J., McIntire, W. S. \& Mathews, F. S. (1998). Acta Cryst. D54, 253-268.

Cromer, D. T. (1974). International Tables for X-ray Crystallography, Vol. IV, p. 149. Birmingham: Kynoch Press. (Present distributors: Kluwer Academic Publishers, Dordrecht.)

Cromer, D. T. \& Waber, J. T. (1974). International Tables for X-ray Crystallography, Vol. IV, p. 99. Birmingham: Kynoch Press. (Present distributors: Kluwer Academic Publishers, Dordrecht.)

Crowther, R. A. (1972). The Molecular Replacement Method, pp. 173178. New York: Gordon and Breach.

Daizadeh, I., Medvedev, E. S. \& Stuchebrukhov, A. A. (1997). Proc. Natl Acad. Sci. USA, 94, 3703-3708.

Day, M. W. (1995). PhD thesis, California Institute of Technology, USA.

Di Bilio, A. J., Hill, M. G., Bonander, N., Karlsson, B. G., Villahermosa, R. M., Malmström, B. G., Winkler, J. R. \& Gray, H. B. (1997). J. Am. Chem. Soc. 119, 9921-9922.

Duchamp, D. (1964). Am. Crystallogr. Assoc. Meet., p.29, Abstract B14.

Faham, S., Mizoguchi, T. J., Adman, E. T., Gray, H. B., Richards, J. H. \& Rees, D. C. (1997). J. Biol. Inorg. Chem. 2, 464-469.

Farver, O. \& Pecht, I. (1997). J. Biol. Inorg. Chem., 2, 387-392.

Fee, J. A. (1975). Struct. Bonding, 23, 1-60.

Fraga, E., Webb, M. A. \& Loppnow, G. (1996). J. Chem. Phys. 100, 3278-3287.

Gehlen, J. N., Daizadeh, I., Stuchebrukhov, A. A. \& Marcus, R. A. (1996). Inorg. Chim. Acta, 243, 271-282.

Gray, H. B. \& Winkler, J. R. (1996). Annu. Rev. Biochem. 65, 537-561.

Hope, H. (1988). Acta Cryst. B44, 22-26.

Hope, H. (1990). Annu. Rev. Biophys. Chem. 19, 107-126.

Howard, A. J., Gilliland, G. L., Finzel, B. C., Poulos, T. L., Ohlendorf, D. H. \& Salemme, F. R. (1987). J. Appl. Cryst. 20, 383-387.

Janin, J., Miller, S. \& Chothia, C. (1988). J. Mol. Biol. 204, 155-164.

Johnson, E. C., Sullivan, B. P., Salmon, D. J., Adeyemi, S. A. \& Meyer, T. J. (1978). Inorg. Chem. 17, 2211-2214.

Kimura, T., Sakurai, T., Shima, M., Nagai, T., Mizumachi, K. \& Ishimori, T. (1982). Acta Cryst. B38, 112-115.

Kraulis, P. J. (1991). J. Appl. Cryst. 24, 946-950.

Laskowski, R. A., MacArthur, M. W., Moss, D. S. \& Thornton, J. M. (1993). J. Appl. Cryst. 26, 283-291.

Matthews, B. W. (1968). J. Mol. Biol. 33, 491-497.

Merritt, E. A. \& Murphy, M. E. P. (1994). Acta Cryst. D50, 869-873.

Nar, H., Messerschmidt, A., Huber, R., van de Kamp, M. \& Canters, G. W. (1991a). J. Mol. Biol. 218, 427-447.

Nar, H., Messerschmidt, A., Huber, R., van de Kamp, M. \& Canters, G. W. (1991b). J. Mol. Biol. 221, 765-772.

Piccioli, M., Luchinat, C., Mizoguchi, T. J., Ramirez, B. E., Gray, H. B. \& Richards, J. H. (1995). Inorg. Chem. 34, 737-742.

Regan, J. J., Di Bilio, A. J., Langen, R., Skov, L. S., Winkler, J. R., Gray, H. B. \& Onuchic, J. N. (1995). Chem. Biol. 2, 489-496.

Regan, J. J., Di Bilio, A. J., Winkler, J. R., Richards, J. H \& Gray, H. B. (1988). Inorg. Chim. Acta, 275/276, 470-480.

Skov, L. K., Pascher, T., Winkler, J. R. \& Gray, H. B. (1998). J. Am. Chem. Soc. 120, 1102-1103.

Solomon, E. I., Penfield, K. W., Gewirth, A. A., Lowery, M. D., Shadle, S. E., Guckert, J. A. \& LaCroix, L. B. (1996). Inorg. Chim. Acta, 243, 67-78.

Stephens, F. S., Vagg, R. S. \& Williams, P. A. (1983). Inorg. Chim. Acta, 72, 253-261.

Stuchebrukhov, A. A. (1996). J. Chem. Phys. 104, 8424-8432.

Tronrud, D. E., Ten Eyck, L. F. \& Matthews, B. W. (1987). Acta Cryst. A23, 489-501.

Winkler, J. R. \& Gray, H. B. (1997). J. Biol. Inorg. Chem. 2, 399-404. 